\title{
SUMMARY
}

Odheretna Olha. Economic potential of acmeological technologies in improving quality of vocational education.

At the turn of the XX and XXI centuries the issue of the quality of education, its measurement is the subject of interest of the scientists, educational management and public institutions. The quality of education and its evaluation depends on the needs of the state, its development strategy. Recent reforms and definitions of the way of development of the state according to the democratic principle of European education strategies actualize not only the issue of social need, but also the personal needs of each future specialist, giving him the opportunity to freely choose the trajectory of professional formation, self-realization and self-development.

Taking into account the conditionality of almost all aspects of state development, including the quality of education, economic pedagogy pays special attention to this issue. This is manifested through a scientific reflection of such a quality as economic competence. It is substantiated that economic issues permeate all spheres of human life, determine its economic behavior in various spheres. In the context of the quality of education, it addresses both the needs of society and the needs of the individual. It is specified that the economic sphere of the future specialist is manifested in such aspects that become factors of the quality of education in accordance with modern market conditions: personality-need, humanistic, professional-activity, value-orientation.

It is shown that the mechanism of stimulating development of the economic sphere of the person can be acmeological technologies that meet all relevant aspects of the current economic problems. The economic potential of acmeological technologies has been determined - it is an effective mechanism of pedagogical influence on the creation of an atmosphere of the educational process, application of appropriate conditions that ensure the entry (directly or indirectly, real and virtual) of the future specialist into the economic segment of society in the process of professional training on the basis of interest, adaptive capacity, readiness of the individual to use effectively their own human resources.

Key words quality of education, economic competence of the future specialist, acmeological technologies, economic potential of acmeological technologies.

Удк 378. 14: 796. 011.3

Антоніна Розсоха

ДВНЗ «Переяслав-Хмельницький ДПУ імені Григорія Сковороди» ORCID ID 0000-0001-8877-4243

Михайло Кравець

ДВНЗ «Переяслав-Хмельницький ДПУ імені Григорія Сковороди»

ORCID ID 0000-0001-7677-1416

DOI 10.24139/2312-5993/2019.07/276-285

\section{ПЕДАГОГІЧНІ УМОВИ ПІДГОТОВКИ МАЙБУТНІХ УЧИТЕЛІВ ФІЗИЧНОЇ КУЛЬТУРИ ДО КРАЄЗНАВЧОЇ ДІЯЛЬНОСТІ}

У статті здійснено аналіз педагогічних умов підготовки майбутніх учителів фізичної культури до краєзнавчої діяльності. Обгрунтовано актуальність дослідження проблеми ефективної організачії підготовки майбутніх учителів 
фізичної культури до краєзнавчої діяльності на засадах компетентнісного підходу. Аналіз науково-теоретичних джерел свідчить про неоднозначний підхід до розуміння дослідниками і практиками цієї проблеми.

Проаналізована організація освітнього процесу, який спрямований на формування готовності майбутніх учителів фрізичної культури до краєзнавчої діяльності, що полягає у створенні умов для формування у студентів досвіду означеної діяльності, різних способів практичної діяльності, ціннісного ставлення до навколишньої дійсності.

Ключові слова: професійна підготовка вчителя, освітній процес, краєзнавча діяльність, фізична культура, компетентність, педагогічні технології.

Постановка проблеми. Соціально-економічні зміни в житті українського суспільства, пов'язані з переходом до його демократичної моделі, позитивно вплинули на розвиток системи професійної підготовки майбутніх фахівців у закладах вищої освіти. Водночас, однією з актуальних проблем залишається підготовка майбутнього вчителя до краєзнавчої діяльності. У цьому контексті набуває наукової доцільності та суспільної своєчасності проблема формування краєзнавчої компетентності майбутніх учителів фізичної культури.

Теоретична і практична підготовка майбутніх учителів фізичної культури до організації краєзнавчої діяльності на засадах компетентнісного підходу зумовлена особливостями професійної підготовки, зокрема, організацією освітнього процесу, застосуванням відповідних технологій навчання, способом рефлексії та практичної реалізації отриманих знань, умінь і навичок. У той час удосконалення та реформування освітнього середовища закладів загальної середньої освіти вимагає розроблення й упровадження нових форм, принципів, методів фахової підготовки майбутніх учителів фізичної культури відповідно до вимог сьогодення. Тому виникає проблема ефективної організації підготовки майбутніх учителів фізичної культури до краєзнавчої діяльності на засадах компетентнісного підходу як цілеспрямованого педагогічного процесу на зміст сучасної освіти.

Аналіз актуальних досліджень. Теоретичні і методологічні підходи до професійної підготовки майбутніх учителів фізичної культури обґрунтовуються в працях О. Дубогай, В. Кашуби, Т. Круцевич, Н. Пангелової, С. Харченка, Ю. Пелеха, Б. Шияна.

Підготовка майбутніх учителів фізичної культури до туристськокраєзнавчої діяльності розглядається в працях Г.Омельчука, Ю. Соловйової, Т. Петухової, В. Чернякова та інші.

Аналіз дисертаційних робіт науковців Н. Степанченко, П. Джуринського, В. Обозного, Л. Чалій, І.Ткачівської, Н. Брижак, Г.Попович свідчить, що питання обґрунтування педагогічних умов підготовки майбутніх учителів фізичної культури до краєзнавчої діяльності на засадах компетентнісного підходу $€$ нагальним у сучасних наукових дослідженнях. 
Мета дослідження - теоретично обґрунтувати педагогічні умови підготовки майбутніх учителів фізичної культури до краєзнавчої діяльності, визначити зміст, форми, методи навчання, що сприяють організації краєзнавчої діяльності на засадах компетентнісного підходу.

У процесі дослідження були використані теоретичні методи: аналіз сучасних нормативних документів, психолого-педагогічної літератури, навчально-методичних матеріалів із метою розуміння проблеми підготовки майбутніх учителів фізичної культури до краєзнавчої діяльності на засадах компетентнісного підходу.

Виклад основного матеріалу дослідження. Методологічний аспект обгрунтування системи педагогічних умов, що складає потенціал для краєзнавчої діяльності майбутніх учителів фізичної культури, базується на системному, акмеологічному, особистісно орієнтованому, інтегративному та компетентнісному підходах до освітнього середовища закладів вищої освіти. Означені методологічні підходи дозволять спроектувати ефективну модель та педагогічні умови, зокрема, підготовки майбутніх учителів фізичної культури до краєзнавчої діяльності на засадах компетентнісного підходу.

Так, Н. Степанченко відмічає, що стосовно фізичного виховання педагогічні умови слушно визначають як таку організацію навчальновиховного процесу, що відображає узгоджену діяльність педагога й учнів (студентів), що проводиться в належному порядку та відповідно до встановленого режиму (Степанченко, 2017, с. 87). Дослідниця обґрунтовує психолого-педагогічні умови вдосконалення системи професійної підготовки майбутніх учителів у закладах вищої освіти, а саме: цілеспрямовану мотивацію студентів і викладачів до навчання та педагогічної діяльності; поглиблення змісту професійно спрямованого навчання з психологічних і педагогічних дисциплін; комплексне системно-цільове проектування професійної підготовки; застосування інноваційних технологій, спрямованих на розвиток педагогічної майстерності вчителя (Степанченко, 2017).

О. Безкопильний та Л. Сущенко акцентують увагу на тому, що 3 позицій сьогодення важливим $\epsilon$ розроблення нових підходів до вдосконалення системи підготовки майбутніх учителів фізичної культури 3 метою підвищення їх конкурентоспроможності на ринку праці, готовності до постійного професійного зростання та здатності ефективно реалізовувати весь спектр завдань фізичного виховання учнів закладів загальної середньої освіти. У дослідженні підготовку майбутніх учителів фізичної культури до здоров'язбережувальної діяльності в основній школі науковці пропонують забезпечувати за рахунок таких організаційнопедагогічних умов: забезпечення інтеграції теоретичної та практичної підготовки майбутніх учителів фізичної культури, міждисциплінарних зв'язків і наступності в навчально-виховному процесі; розвиток творчого 
потенціалу майбутніх учителів фізичної культури за рахунок запровадження інноваційних освітніх технологій; застосування інформаційно-комунікаційних технологій, які суттєво підвищать якість навчання; формування досвіду здоров'язбережувальної діяльності в основній школі та опанування засобами вирішення професійних завдань щодо фізичного виховання учнів (Безкопильний, 2018, с. 47-53).

Одним із вагомих наукових напрацювань щодо даного питання вважаємо дослідження І.Ткачівської, яка вивчає проблему підготовки майбутніх учителів фізичної культури до туристсько-краєзнавчої роботи $з$ учнями. Дослідниця відмічає, що для забезпечення успішного функціонування моделі підготовки майбутніх учителів фізичної культури до туристсько-краєзнавчої діяльності необхідно забезпечити наступні педагогічні умови: формування національної самосвідомості засобами туристсько-краєзнавчої роботи; поглиблене вивчення краєзнавства та пізнавально-рекреаційних можливостей краю; реалізація міжпредметних зв'язків між туристсько-краєзнавчими та спортивними дисциплінами; навчально-методичне забезпечення викладання туристсько-краєзнавчих дисциплін. Поділяємо думку І.Ткачівської, що поглиблене вивчення краєзнавства та пізнавально-рекреаційних можливостей краю забезпечується завдяки включенню краєзнавчого матеріалу до змісту вивчення дисциплін туристсько-краєзнавчого циклу, оскільки саме краєзнавство має значний потенціал для міцного засвоєння студентами основ наук, унаслідок чого розширюються й поглиблюються їхні знання, розвиваються творчі здібності, інтерес до туристсько-краєзнавчої діяльності, активно формується світогляд (Ткачівська, 2009).

Вважаємо, що педагогічні умови результативного формування краєзнавчої компетентності майбутніх учителів фізичної культури являють собою комплекс заходів, що забезпечують реалізацію в навчальному процесі спроектованої моделі. У підготовці майбутніх учителів фізичної культури до краєзнавчої діяльності мають бути диференційовані наступні педагогічні умови: 1) стимулювання позитивної мотивації майбутніх учителів фізичної культури до засвоєння змісту навчального матеріалу 3 організації краєзнавчої діяльності; 2) удосконалення змісту навчального матеріалу дисциплін циклу загальної (фундаментальної) і професійної (науково-предметної) підготовки 3 питань організації краєзнавчої діяльності; 3) визначення форм, методів і засобів навчання, що сприяють організації краєзнавчої діяльності на засадах компетентнісного підходу; 4) набуття майбутніми вчителями фізичної культури досвіду краєзнавчої діяльності під час навчальних і педагогічних практик.

Стимулювання позитивної мотивації майбутніх учителів фрізичної культури до засвоєння змісту навчального матеріалу з організації краєзнавчої діяльності - перша педагогічна умова, для якої характерна 
наявність ціннісних установок і мотивів у майбутніх учителів фізичної культури, спрямованих на реалізацію краєзнавчої діяльності.

Майбутні вчителі фізичної культури повинні володіти вміннями органічно поєднувати та професійно реалізовувати навчальні, розвивальні та виховні завдання в контексті краєзнавчої діяльності на основі внутрішньої вмотивованості до цієї діяльності та високого рівня сформованості відповідних компетентностей. Вважаємо, що одним із завдань ефективної підготовки майбутніх учителів фізичної культури до краєзнавчої діяльності $€$ формування власної мотивації до застосування організаційних форм краєзнавчої роботи в майбутній фаховій діяльності на основі усвідомлення особистісно-орієнтованої, соціально-педагогічної та психологічної цінності краєзнавчого навчального матеріалу в контексті компетентнісного підходу.

Друга педагогічна умова - удосконалення змісту навчального матеріалу дисциплін циклу загальної (фундаментальної) і професійної (науково-предметної) підготовки з питань організачії краєзнавчої діяльності - передбачала відбір і конструювання змісту навчальних дисциплін із метою забезпечення комплексності результату професійної підготовки майбутніх учителів фізичної культури до краєзнавчої діяльності. Фахова діяльність учителя фізичної культури, яка спрямована на розвиток краєзнавчої діяльності учнів актуалізує необхідність поглиблення психолого-педагогічних знань, оволодіння практичними вміннями й навичками, вимагає творчої ініціативи, високого рівня професійної та методологічної культури, краєзнавчої компетентності в організації навчально-виховного процесу.

у педагогічних закладах вищої освіти та класичних університетах туристсько-краєзнавча робота реалізується в ході вивчення таких дисциплін, як «Основи екології», «Історичне краєзнавство», «Історія рідного краю», «Літературне краєзнавство», «Краєзнавчо-туристична діяльність», «Основи краєзнавчо-туристської діяльності», «Туристичні ресурси українського регіону», «Основи екскурсознавства», «Основи музеєзнавства», «Археологія України», «Етнографія», «Туризм», «Основи туризму», «Організаційнотуристська робота», «Етнологія» (Прокопчук, 2010).

Вважаємо, що зміст навчального матеріалу доцільно доповнити такими модулями й темами, що впливатимуть на розвиток особистості майбутніх учителів фізичної культури, на формування відповідної системи знань, умінь і навичок, необхідних для організації краєзнавчої діяльності на засадах компетентнісного підходу.

Третя педагогічна умова - визначення фрорм, методів $і$ засобів навчання, що сприяють організачії краєзнавчої діяльності на засадах компетентнісного підходу. На нашу думку, ця умова передбачає застосування відповідних методів, прийомів та форм організації 
навчально-виховного процесу, що спрямовані на формування готовності майбутніх учителів фізичної культури до ефективної методики організації і проведення різних видів краєзнавчої діяльності, використання краєзнавчого матеріалу в навчально-виховному процесі 3 учнями. Відмітимо, що завдання формування готовності майбутніх учителів фізичної культури до краєзнавчої діяльності на засадах компетентнісного підходу передбачає розв'язання питання щодо вибору релевантних форм, методів і засобів навчання.

Організація освітнього процесу, який спрямований на формування готовності майбутніх учителів фізичної культури до краєзнавчої діяльності, полягає у створенні умов для формування у студентів досвіду означеної діяльності, різних способів практичної діяльності, а також ціннісного ставлення до навколишньої дійсності.

Отже, ефективність підготовки майбутніх учителів фізичної культури до краєзнавчої діяльності може бути підвищена за умов комплексного вдосконалення форм і методів навчального процесу: упровадження мультимедійних технологій на лекційних заняттях та реалізацію інформаційнокомунікаційних технологій у процесі проведення практичних занять.

Четверта педагогічна умова - набуття майбутніми вчителями фізичної культури досвіду краєзнавчої діяльності під час навчальних $i$ педагогічних практик. За словами А. Макаренка, у процесі розвитку краєзнавчої діяльності створюються сприятливі умови для соціалізації молоді: «Мета і завдання нашого виховання повинні бути виведені не 3 чогось абстрактного, незнайомого кожній людині, а з нашої історії, 3 нашого суспільного життя» (Макаренко, 1990). Педагог вважав, що людську особистість, її характер, темперамент, трудові й розумові навички слід формувати на основі того краєзнавчого матеріалу, який притаманний тому чи іншому регіону, у якому проживає вихованець і доносити до його свідомості насамперед здобутки свого народу, оскільки ніщо так не впливає на формування особистості, як традиція. На його думку, саме краєзнавчі здобутки сприяють гармонійному розвитку особистості. Не можна упустити й те, що А. Макаренко для виховання в колективі і через колектив використовував екскурсії та екскурсійно-туристичні походи 3 метою вивчення природи й історії Вітчизни (Блажко, 2017, с. 65-69).

У структурі особистості, зазначає В.Кремень, важливе місце відводиться саме краєзнавчій діяльності особистості, сутність якої складає любов до рідного краю, патріотизм, інтерес і творче ставлення до краєзнавчої роботи, потреба у здобутті краєзнавчих знань завдяки вивченню історичного минулого й шанобливого ставлення до спадщини, народних традицій і звичаїв (Кремень, 2011, с. 10-15).

Краєзнавча діяльність майбутніх учителів фізичної культури повинна будуватися на таких принципах: 
1. Патріотична спрямованість. Краєзнавча діяльність підпорядкована формуванню національної свідомості, любові і гордості за свій край, його героїчне минуле, патріотизму - готовності захищати свою Вітчизну, розбудовувати та зміцнювати ії суверенітет, незалежність.

2. Науковість. Вивчення має будуватися на міцному науковотеоретичному ґрунті, знанні форм і методів дослідницької роботи.

3. Природовідповідність. Цей принцип вимагає врахування природних можливостей дітей-дошкільнят, окремо - учнів 1-4, 5-9, 10-12 класів, дбати, щоби зміст та обсяг краєзнавчих досліджень був посильним, доступним, відповідав інтересам, віковим можливостям дітей.

4. Оптимальне поєднання дослідної й суспільно корисної діяльності. На основі вивченого слід створювати краєзнавчі кутки, музейні експозиції, доглядати за могилами загиблих, пам'ятниками, поширювати краєзнавчі знання.

5. Комплексність. У ході вивчення краю використовувати міжпредметні зв'язки, адже навіть похід чи експедиція - це дотик до природи, історії, культури його населення, географії, економіки, людського побуту, етнографії і фольклору краю.

6. Систематичність. Шкільна краєзнавча робота має здійснюватися не тільки по всіх напрямах, а й упродовж навчального року, канікул, усього шкільного періоду.

7. Планомірність. Робота не повинна проводитися стихійно, у річному плані школи, класних керівників, керівників гуртків, музею передбачаються заходи, дати, виконавці.

8. Наступність, скоординованість. Реалізується переходом від рівня нижчого до вищого, а також - установленням зв'язків між різновіковими туристсько-краєзнавчими формуваннями - товариствами, гуртками, факультативами (Пангелова, 2015).

Висновки. Сучасний учитель фізичної культури поряд із навчанням і вихованням учнів здійснює культурологічну, соціально-психологічну, розвивальну, дослідницьку функції, створює умови, що забезпечують освітній, фізичний і духовний розвиток учнів. Його фахова досконалість усе більше характеризується рівнем компетентності, що визначає ефективність і результативність педагогічних дій. Підготовка майбутніх учителів фізичної культури до краєзнавчої діяльності учнів забезпечується системою педагогічних умов: стимулювання позитивної мотивації майбутніх учителів фізичної культури до засвоєння змісту навчального матеріалу з організації краєзнавчої діяльності; удосконалення змісту навчального матеріалу дисциплін циклу загальної (фундаментальної) і професійної (науковопредметної) підготовки з питань організації краєзнавчої діяльності; визначення форм, методів і засобів навчання, що сприяють організації краєзнавчої діяльності на засадах компетентнісного підходу; набуття 
майбутніми вчителями фізичної культури досвіду краєзнавчої діяльності під час навчальних і педагогічних практик. Такі педагогічні умови визначено як особливості динаміки навчально-виховного процесу, що детермінують результати виховання, освіти та професійного розвитку й об'єктивно забезпечують можливість їх досягнення. Аналіз науковотеоретичних джерел свідчить про неоднозначний підхід до розуміння дослідниками і практиками цієї проблеми.

Перспективи подальших наукових розвідок. Досліджувана проблема $€$ багатоаспектною i передбачає продовження науковопошукової роботи. Перспективні напрями вбачаємо в дослідженні проблеми цілісного процесу підготовки майбутніх учителів фізичної культури до системи краєзнавчих знань і краєзнавчої діяльності, його моделюванні й обґрунтуванні педагогічних умов реалізації, розробці відповідних інтерактивних технологій і методик формування краєзнавчої компетентності у співпраці краєзнавчих музеїв, органів державного самоврядування, краєзнавчих спілок.

\section{ЛІТЕРАТУРА}

Безкопильний, О.(2018). Моделювання процесу підготовки майбутніх учителів фізичної культури до здоров'язбережувальної діяльності в основній школі. Наукові записки Тернопільського національного педагогічного університету імені Володимира Гнатюка. Сер. Педагогіка, 1, 47-53 (Bezkopylnyi, 0. (2018). Modeling the process of preparing future physical education teachers for health-care activities in primary school. Scientific notes of the Ternopil National Pedagogical University named after Volodymyr Hnatyuk. Series Pedagogy, 1, 47-53).

Кремень, В. (2011). Вітчизняне краєзнавство: стратегічні орієнтири сучасної освітньої парадигми. Краєзнавство, 3, 10-15 (Kremen, V. (2011). Domestic history: strategic guidelines of the modern educational paradigm. Local History, 3, 10-15).

Макаренко, А. С. (1990). Методика виховної роботи. К.: Рад. шк. (Makarenko, А. S. (1990). M ethods of educational work. Kyiv).

Блажко, О.А. (2017). Роль краєзнавства у професійній підготовці майбутніх учителів початкових класів. Вісник Житомирського державного університету імені Івана Франка. Педагогічні науки, 2 (88), 65-69 (Blazhko, О. А. (2017). The role of local history in the vocational training of future primary school teachers. Bulletin of Zhytomyr Ivan Franko State University. Pedagogical Sciences, 2 (88), 65-69).

Обозний, В. В. (2018). Теоретико-методологічні засади освітньої стратегії розвитку регіонального туризму. Молодий вчений: науковий журнал, 4.2 (56.2), 141-146 (Oboznyi, V. V. (2018). Theoretical and methodological foundations of the educational strategy for the development of regional tourism. Young Scientist: Scientific Journal, 4.2 (56.2), 141-146).

Пангелова, Н. Є. (2015). Теоретико-методичні засади туристсько-краєзнавчої роботи у вищих навчальних закладах: [навч.-метод. посібн.]. Переяслав-Хмельницький: ФОП Лукашевич О.M. (Pangelova, N. Е. (2015). Theoretical and methodological foundations of tourism and local lore in higher education: [teaching-method. manual]. Pereiaslav-Khmelnitskyi: FOP Lukashevych O. M.). 
Прокопчук, В. С. (2010). Шкільне краєзнавство: навчальний посібник. Кам'янецьПодільський нац. ун-т ім. Івана Огієнка. Київ, Кам'янець-Подільський: Кондор (Prokopchuk, V. S. (2010). School history: a textbook. Kamianets-Podilskyi Nat. University named after Ivan Ogienko. Kyiv, Kamianets-Podilskyi: Kondor).

Степанченко, Н. І. (2017). Система професійної підготовки майбутніх учителів фрізичного виховання у вищих навчальних закладах (дис. ... д-ра пед. наук: 13.00.04). Вінниця (Stepanchenko, N. I.. The system of professional training of future teachers of physical education in higher educational establishments (DSc thesis). Vinnytsia).

Ткачівська, І. М. (2009). Підготовка майбутніх учителів фрізичної культури до туристсько-краєзнавчої роботи з учнями (автореф. дис. ... канд. пед. наук : 13.00.04). Тернопіль (Tkachivska, I. М. (2009). Preparation of future teachers of physical culture for tourism and local lore with students (PhD thesis abstract). Ternopil).

Rozhi, I. (2016). The competency-based approach in the context of future geography teachers training to the regional natural history and tourism work. Intellectual Archive, 73-90.

\section{PEЗЮME}

Розсоха Антонина, Кравец Михаил. Педагогические условия подготовки учителей физической культуры к краеведческой деятельности.

В статье осуществлен анализ педагогических условий подготовки будущих учителей физической культуры к краеведческой деятельности. Обоснована актуальность проблемы исследования эфррективной организации подготовки будущих учителей физической культуры к краеведческой деятельности на основе компетентностного подхода. Научно-теоретические источники свидетельствуют о неоднозначном подходе к пониманию исследователями и практиками этой проблемы. Проанализирована организация образовательного процесса, направленного на формирование готовности будущих учителей фризической культуры к краеведческой деятельности, которая заключается в создании условий формирования у студентов опыта указанной деятельности, ценностного отношения к родному краю.

Ключевые слова: профессиональная подготовка учителя, образовательный прочесс, краеведческая деятельность, физическая культура, компетентность, педагогические технологии.

\section{SUMMARY}

Rozsokha Antonina, Kravets Mykhailo. Pedagogical conditions of preparing physical culture teachers for local lore activity.

The article analyzes pedagogical conditions of preparation of future teachers of physical culture for local lore activity. The relevance of research into the problem of effective organization of training of future physical education teachers for local lore based on competence approach is substantiated. The analysis of scientific-theoretical sources shows an ambiguous approach to understanding by researchers and practitioners of this problem. The issues related to building a comprehensive process of preparing future physical education teachers for the system of local lore based on a competence approach remain poorly understood.

It is noted that improvement and reformation of the educational environment of general education institutions requires development and implementation of new forms, principles, methods of professional training of future physical education teachers in 
accordance with the requirements of today. That is, organization of the educational process, which aims at shaping the willingness of future teachers of physical education to study in local lore, is to create conditions for students to form the experience of a particular activity, different ways of practical activity, as well as the value attitude to the surrounding reality.

On the basis of the analysis of scientific sources, pedagogical conditions of preparation of future physical culture teachers for local lore activity are substantiated, namely: stimulation of positive motivation of future physical education teachers for assimilation of the content of educational material on organization of local lore; improvement of the content of the educational material of the disciplines of the cycle of general (fundamental) and professional (scientific-subject) training on the issues of organization of local lore; identifying forms, methods and teaching aids that facilitate organization of local lore on the basis of a competence approach; acquisition of experience of local lore by future teachers of physical culture during educational and pedagogical practices.

Key words professional teacher training, educational process, local lore, physical culture, competence, pedagogical technologies.

удк 378.6.656

Олена Саркісова

Льотна академія

Національного авіаційного університету

ORCID ID 0000-0002-3022-1395

DOI 10.24139/2312-5993/2019.07/285-293

\section{СТРУКТУРНІ КОМПОНЕНТИ МОДЕЛІ ФОРМУВАННЯ ПРОФЕСІЙНОГО СТАНОВЛЕННЯ МАЙБУТНІХ МЕНЕДЖЕРІВ АВІАЦІЙНОЇ ГАЛУЗІ У ПРОЦЕСІ ФАХОВОЇ ПІДГОТОВКИ}

У статті розкривається модель формування професійного становлення менеджерів авіаційної галузі у процесі фахової підготовки. На основі методу наукового моделювання визначено основні структурні елементи моделі, схарактеризовано їх сутність та взаємозв'язки. Модель складається з чотирьох взаємопов'язаних етапів, а саме: організаційного, змістового, процесуального та оцінно-результативного. Аналізується зміст кожного етапу. На основі розроблених компонентів, критеріїв і показників виокремлено три рівні професійного становлення: високий (професійний), середній (достатній) та низький (базовий), що потребує корегування процесу формування професійного становлення.

Ключові слова: етапи професійного становлення, менеджер авіаційної галузі, модель, моделювання, професійне становлення.

Постановка проблеми. Професійне становлення фахівців, зокрема менеджерів авіаційної галузі, набуває особливого значення в умовах мінливої дійсності, особливо під час соціально-економічних перетворень, що наразі відбуваються в суспільстві. Вища освіта в умовах сьогодення повинна створювати необхідні умови для підготовки майбутнього конкурентоспроможного фахівця, який буде відповідати сучасним вимогам ринку праці. Зокрема, менеджер авіаційної галузі $\epsilon$ однією з ключових професій у світі авіації, який $є$ професійним керівником, здійснює 